\title{
Description of a new species of Paratropus Gerstaecker, 1867 (Coleoptera: Histeridae) from Vietnam
}

\author{
Описание нового вида Paratropus Gerstaecker, 1867 \\ (Coleoptera: Histeridae) из Вьетнама
}

\author{
Alexander V. Sokolov \\ Александр В. Соколов
}

Ltd. Service Aqua, Severniy bulvar 12V, 84, Moscow 127490, Russia. E-mail: margarinotus@yandex.ru. ООО «Сервис Аква», Северный бульвар 12в, 84, Москва 127490, Россия.

KEY WORDS: Coleoptera, Histeridae, Exosternini, Paratropus fedorenkoi, new species, Vietnam. КЛЮЧЕВЫЕ СЛОВА: Coleoptera, Histeridae, Exosternini, Paratropus fedorenkoi, новый вид, Вьетнам.

ABSTRACT. Description of new species of clownbeetles, Paratropus fedorenkoi sp. n. from southern Vietnam, is given. The description based on a single female specimen collected by window traps.

РЕЗЮМЕ. Описывается новый вид Paratropus fedorenkoi sp. n. из южного Вьетнама. Описание базируется на одном экземпляре (самке), собранной оконными ловушками.

\section{Introduction}

The myrmecophilous and termitophilous genus Paratropus Gerstaecker, 1867 is distributed in tropical forests and savannas of Africa and Oriental Region. The genus comprises 84 described species, including only eleven Oriental species [Kanaar, 1997, 2004; Mazur, 2011]. Numerous African Paratropus specimens were collected in decaying substrates and even were attracted to lights, but a substantial part of species known only from few specimens and requires specific collecting methods. Many species are hard to distinguish, especially without examination of male genitalia. This paper is based unique female specimen, which however noticeably differs from rest species of the genus. During expedition sponsored by RussianVietnamese Tropical Centre were collected numerous uncommon and undescribed histerids including this new Paratropus species. Measurements are abbreviated as follows: L — total length of pronotum and elytra, without head, propygidium and pygidium, Lp — pronotal length, Le - length of elytron along elytral suture, $\mathrm{Wpb}$ - pronotal width across base, We - elytral width across humeri, $\mathrm{H}$ - distance from metaventrite to maximal high of elytra, measured in lateral position.
Genus Paratropus Gerstaecker, 1867

Paratropus fedorenkoi Sokolov, sp.n. Figs 1-3.

MATERIAL. Holotype, + , labeled: "S Vietnam, 120 km NNE Ho Chi Minh, env. Cat Tien Nat. Park h=150-170m. 19.05 18.06.2005 leg. D. Fedorenko Ок.л. 2 / HOLOTYPE Paratropus fedorenkoi sp. n. A. Sokolov des. 2019." Holotype is deposited in author's collection.

DESCRIPTION. Habitus as illustrated (Figs 1-2). L=3.6 $\mathrm{mm}, \mathrm{We}=2.9 \mathrm{~mm}, \mathrm{H}=2.0 \mathrm{~mm}$. Body broadly oval, strongly convex. Colour reddish brown, darker along sutures, shiny, legs and antennae ferrugineous. Dorsal surface smooth, very feeble punctures visible at $60 \mathrm{X}$ magnification only. Head (Fig. 3). Labrum strongly emarginate. Clypeus transversely concave, planes of clypeus and front forming distinct angle. Frontal stria complete, semihexagonal, with rounded angles. Interocular margins slightly divergent anterad. Frontal impression barely marked. Eyes flat in dorsal view.

$\mathrm{Lp}=1.6 \mathrm{~mm} . \mathrm{Wpb}=2.6 \mathrm{~mm}$. Pronotum about 1.6 times wider than long along the median line, convex, pronotal sides strongly convergate to front. Marginal striae obsolete. Lateral stria complete, anterior marginal stria not interrupted, there is pair poorly visible punctures behind the eyes. Antescutellar pronotal impression indistinct.

$\mathrm{Le}=2.0 \mathrm{~mm}$. We $=2.9 \mathrm{~mm}$. Epipleural striae obsolete, epipleurae convex, smooth. Outer subhumeral striae complete. Inner subhumeral stria absent. Dorsal striae reduced, 1st striae only present, reaching slightly beyond the middle of elytra posteriorly. Humeral stria poorly visible. Propygidium and pygidium smooth, without any punctures and microsculpture. Marginal stria of pygidium fine, interrupted medially at either side, with small fragment present along the apex.

Prosternal lobe truncate and slightly emarginated in front, with well impressed marginal stria, abbreviated at middle. Prosternal keel slightly convex in lateral view, carinal striae fine, slightly divergent anteriorly and markedly posteriorly. Lateral prosternal striae absent. Inner lateral metaventral stria abbreviated anterad, not reaching mesometaventral suture, connected with their recurrent arms forming round loop. There is not

How to cite this article: Sokolov A.V. 2019. Description of a new species of Paratropus (Coleoptera: Histeridae) from Vietnam // Russian Entomol. J. Vol.28. No.2. P.146-147. doi: 10.15298/rusentj.28.2.05 

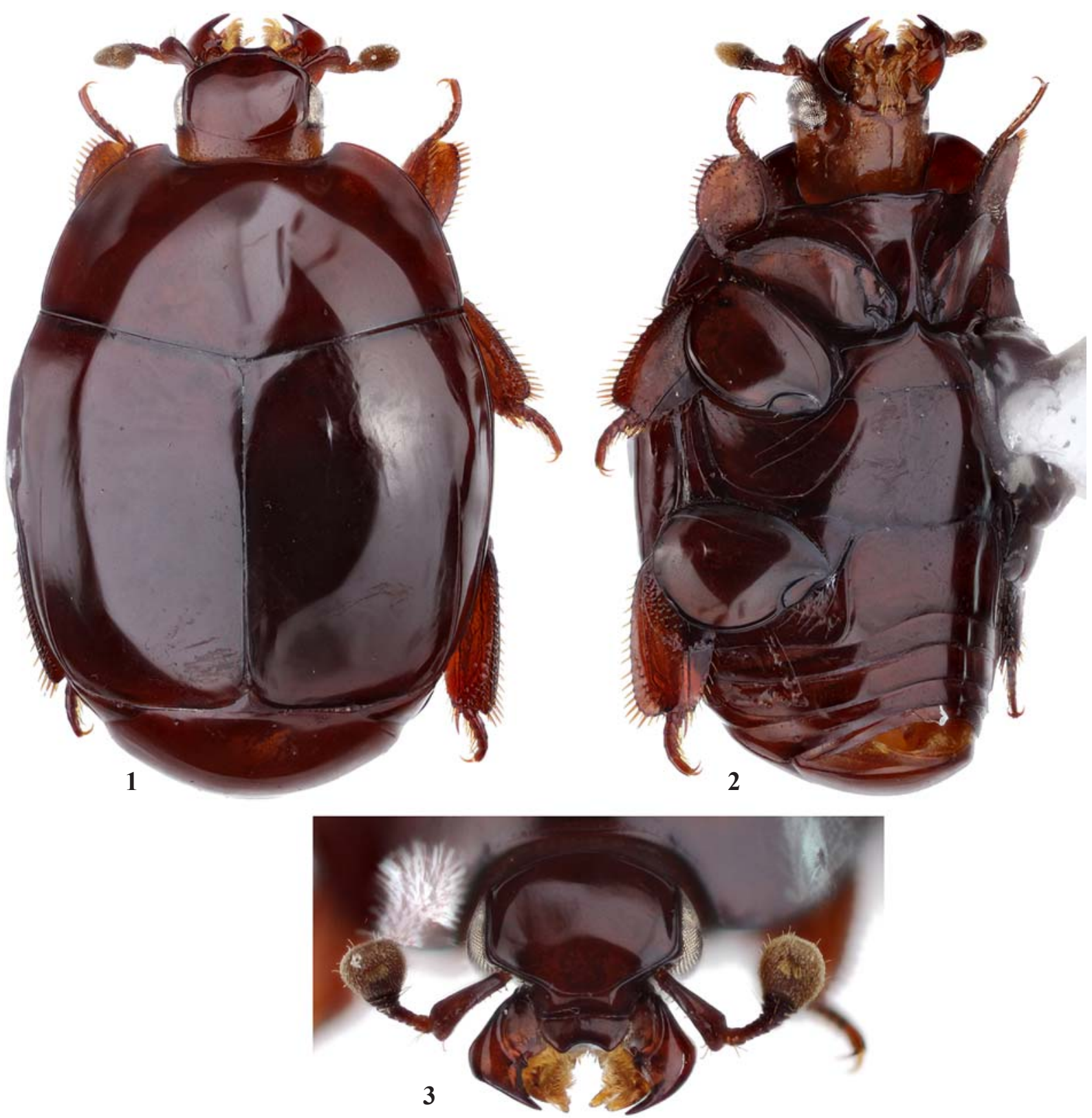

Figs 1-3. Paratropus fedorenkoi sp.n.: 1 - habitus, dorsal view; 2 - ditto, ventral view; 3 - head, dorsal view.

Рис. 1-3. Paratropus fedorenkoi sp.n.: 1 - габитус, сверху; 2 - то же, снизу; 3 - голова, сверху.

punctures on ventral surface. Lateral stria of 1-st abdominal ventrite recurved laterally to hind margin. Legs strongly broadened, linear microsculpture present on inner surface of tibia.

COMPARATIVE REMARKS. Easily distinguished from all species of the genus by the absence of punctures and microsculpture, shortened anteriorly inner lateral metaventral stria, reduced elytral striae and marginal pronotal striae.

ETYMOLOGY. The new species is dedicated to Dr. Dmitriy Fedorenko, who collected this specimen and many other interesting hister-beetles.

BIOLOGY. Single specimen (female) was collected by window traps together with other myrmecophilous and termitophilous histerids, Paratropus termitophilus (Desbordes, 1925) and Ceratohister camelus Tishechkin and Sokolov, 2009. Biotope of collecting is monsoon semidecidous tropical forest.
Acknowledgements. I wish to thank Dr. K.V. Makarov for help with making photographs. Special thanks are due to Dr. A.K. Tishechkin for critical remarks.

\section{References}

Kanaar P. 1997. Revision of the genus Paratropus Gerstaecker (Coleoptera: Histeridae) // Zoologische Verhandelingen, Leiden. P.1-185.

Kanaar P. 2004. Revision of the genus Paratropus Gerstaecker (Coleoptera: Histeridae). II. Supplement // Zoologische Mededelingen, Leiden. Vol.78. No.9. P.181-203.

Mazur S. 2011. A concise catalogue of the Histeridae (Insecta: Coleoptera). Warsaw: Warsaw University of Life Sciences SGGW Press. 332 p. 